\title{
A Comparative Review of National and International Practices in Teacher Education Accreditation
}

\author{
Cusrow J. Dubash ${ }^{1 *}$, Muhammad Adil Arshad ${ }^{2}$, Ammar Husnain Khan $^{3}$ \\ ${ }^{\top}$ Chief Academic Officer, Lampro Mellon IT Solutions, Pvt Ltd, Lahore Pakistan \\ ${ }^{2} \mathrm{PhD}$ Candidate, University of Calgary, Canada \\ ${ }^{3}$ Lecturer, Department of Education, Forman Christian College, Lahore, Pakisthan
}

\section{*Corresponding Author}

Cusrow J. Dubash

\section{Article History}

Received: 27.09 .2020

Accepted: 12.10 .2020

Published: 20.10.2020

\begin{abstract}
In recent years, there has been a pressing need for high-quality teachers in schools. Therefore, greater attention must be paid to all those factors that ensure the highest quality of teacher preparation. Teachers have a critical role to play in our skill-based and technologically enhanced economy where academic underperformers are perceived to be left behind. There is a growing understanding that the surest path to better schools is better teachers, yet when we look around, we find that ensuring high teaching quality is a global challenge. The main goal of Accreditation is to verify that all students are competent teachers and capable. This comparative study reviews the teacher education accreditation processes of four different countries (Scotland, USA, Australia, and Pakistan) and identifies the strengths and weaknesses of each model in their respective contexts.
\end{abstract}

Keywords: Comparative ReviewNational International Education Accreditation.

\section{INTRODUCTION}

There is growing evidence that the quality of teachers is the most important educational resource in our schools, therefore greater attention must be given to the factors that shape that quality. Teachers have engaged themselves on a major role than ever in our technologically enhanced and skill-based economy where academic underperformers are perceived to be left behind [1]. Teacher quality translates directly into students' learning. A well-prepared teacher impacts student assessment more than any other background aspects of student like minority status, language and poverty [2]. Teacher Education (TE) providers should have the capacity and ability to first attract students with high academic potential and then work with them well to meet the ever-evolving demands of learning and teaching in the 21st century. Achieving such capacity in TE providers is a collective responsibility of the nation, university, and the profession.

Internationally, educational practitioners and policymakers have been taking a deep interest in developing adequate accountability and quality assurance procedures for teacher education. Many countries have already accredited their TE programs to ensure better teachers and high quality of instruction in classrooms [3]. Following this global trend, Pakistan's Ministry of Education formed an accrediting agency called the National Accreditation Council for Teacher Education (NACTE), authorized to work under the umbrella of the Higher Education Commission (HEC).

NACTE's primary responsibility is to accredit teacher education programs offered by public and private sector universities all over Pakistan. This paper reviews NACTE's accreditation criteria and procedures in reference to three international models [23]. This study has a two-fold purpose:

- To determine to what extent NACTE's quality assurance procedures and mechanisms are at par with international standards

- To learn certain lessons from successful international accreditation practices and propose improvements for NACTE, if needed

Copyright (C) 2020 The Author(s): This is an open-access article distributed under the terms of the Creative Commons Attribution 4.0 International License (CC BY-NC 4.0) which permits unrestricted use, distribution, and reproduction in any medium for noncommercial use provided the original author and source are credited. 


\section{THEORETICAL FrAMEWORK}

The foremost function of teacher accreditation is to assure the public (in general) that graduates from the specific TE program are professionally qualified and competent to teach. Accreditation determines whether or not any particular TE program justifies to be called a 'School of Education'. This paper follows a comparative approach in inquiring how four different countries, for their respective culture and needs, have developed detailed structures to comprehensively determine whether or not to accredit any given TE program. This review is based on detailed literature analysis and takes into account the national differences and priorities, legal and traditional structures, financial resources and the nature and status of accreditation being offered.

\section{Purpose of Accreditation}

Accreditation, essentially, is both a 'process' and a 'status'. The 'process' reports for the current evaluation and development of educational quality with the improvement and validation of standards while the 'status' offers guarantee to the community that the TE institutions offers the accepted program(s) [4]. Accrediting bodies produce and use certain criterions both to ensure TE programs meet the maximum expectations of quality and also to confirm that they progress over the passage of time. Accreditation standards address fundamental areas such as student support services, budget and resources, literature databases, student learning activities, curricula and faculty. The outcome of the successful accreditation procedure is the grant of "accreditation status".

'Accreditation Status' parallels to the point that students or the community at large can assume that the TE programs will live up to its assurance of producing high quality teachers. With no accreditation status, it is difficult to observe and streamline the working of TE programs. School employers would certainly not be sure whether or not the graduates of unaccredited TE program(s) acquire the right level of teaching proficiency [5]. Few major benefits of accreditation, as identified by NACTE, are:

- Identification of strengths and weaknesses of the program(s) that need to be addressed for further improvement

- Facilitation of individuals in exploring specific program/institution of high quality/standard seeking quality education

- Budgetary provisions and funding for improvement

- Information to prospective funding agencies about what to support and how much to support

- Comparative data for different teacher education institutions

- Development of short and long-term plans for program/institution improvement

- Information to the foreign universities regarding the accreditation status of program attended by Pakistani students seeking admission to their universities

Mostly, in the developed world, accreditation goes hand-in-hand with teacher registration and certification. Pakistan, as of today, doesn't have any authorized body for teacher certification.

\section{ReView Process}

To review teacher education accreditation practices, both nationally and internationally, we collected and analyzed relevant documents, mainly policy reports and research publications. The accreditation bodies reviewed in this paper include General Teaching Council for Scotland (GTCS), Council for the Accreditation of Educator Preparation (CAEP), Australian Institute for Teaching and School Leadership (AITSL)[24], and National Accreditation Council for Teacher Education (NACTE) for Scotland, USA, Australia, and Pakistan respectively.

\section{Each accreditation model has been examined using the following ten parameters:}

1. Overview and Rationale

2. Operational Status

3. Goals

4. Eligibility and Qualification Standards

5. Acknowledgement and Acceptance among Stakeholders

6. Criterion for Assessment

7. Operational Cost

8. Procedures for Conducting the Accreditation Process

9. Duration

10. Complimentary Quality Assessments 
A detailed account of all four accreditation models against the ten parameters is given below:

Table-1: Overview and Rationale

\begin{tabular}{|l|l|}
\hline Scotland & $\begin{array}{l}\text { The General Teaching Council for Scotland (GTCS) was one of the first teaching councils in the world } \\
\text { when it was set up in 1965. In 2012, legislation passed by the Scottish Parliament made it the world's first } \\
\text { independent, self-regulating body for teaching. The Council recommends the approval of initial teacher } \\
\text { education courses/programs to the Scottish Ministers [15]. }\end{array}$ \\
\hline The USA & $\begin{array}{l}\text { Council for the Accreditation of Educator Preparation (CAEP), a national accreditation agency, has evolved } \\
\text { significantly over time. First accrediting body for Teacher Education in the USA whose roots go back to the } \\
\text { 1900s was the AACTE. Then, established in 1954 was NCATE and established in 1997 was TEAC, in their } \\
\text { independent capacities took the responsibility for teacher education Accreditation. However, on July 1, } \\
\text { 2013, both NCATE and TEAC merged into CAEP [12]. }\end{array}$ \\
\hline Australia & $\begin{array}{l}\text { The AITSL was established in January 2010. While AITSL is government funded, it is not at all a } \\
\text { department of the government. AITSL, instead, is a firm limited by guarantee, administered by an impartial } \\
\text { Board of Directors [8]. }\end{array}$ \\
\hline Pakistan & $\begin{array}{l}\text { Higher Education Commission (HEC), a federal body responsible for quality assurance of higher education, } \\
\text { established National Accreditation Council for Teacher Education (NACTE) in December 2006. The } \\
\text { programs conducted by public and private sector colleges and universities, NACTE are authorized to assess } \\
\text { and evaluate the quality of teacher education. While HEC accredits all higher education institutions in } \\
\text { Pakistan, NACTE's responsibility is to accredit the teacher education programs only [9]. }\end{array}$ \\
\hline
\end{tabular}

Table 1 show that all four accreditation bodies have a common purpose of assessing, inspecting and evaluating the quality of teacher education programs in their respective countries. All four accreditation bodies enjoy a good legal standing and authorization and therefore are well recognized among the respective TE providers.

Table-2: Operational Status

\begin{tabular}{|l|l|}
\hline Scotland & $\begin{array}{l}\text { GTCS has always been financially independent, being funded by teachers rather than from the public purse. } \\
\text { On April 2, 2012, the Order conferred independent status on GTC Scotland, together with enhanced powers } \\
\text { and greater flexibility of operation [6]. }\end{array}$ \\
\hline USA & CAEP is a nongovernmental, which is run by volunteers committed to the efficient preparation of teachers [7]. \\
\hline Australia & $\begin{array}{l}\text { AITSL is a national, yet independent, a body founded to endorse and work with quality in teaching and school } \\
\text { leadership [8]. }\end{array}$ \\
\hline Pakistan & $\begin{array}{l}\text { HEC created NACTE for the quality assurance of teacher education programs. NACTE functions as a federal } \\
\text { body under the umbrella of HEC [9]. }\end{array}$ \\
\hline
\end{tabular}

According to Table 2, accreditation bodies for Pakistan and Australia operate nationally and represent the government/nation while both USA and Scotland have non-governmental and privately-administered models. However, it is important to note that all four accreditation bodies, irrespective of their representation (government or private), operate independently to promote excellence in teacher education.

Table-3: Goals

\begin{tabular}{|c|c|}
\hline Scotland & $\begin{array}{l}\text { GTCS strategic objectives: } \\
\text { - Act in the public interest to ensure confidence in our teacher education (TE) institutions/teachers } \\
\text { - Set standards and promote high-quality professional learning for teachers at all stages of their } \\
\text { - } \text { - Strengthen our role in enhancing professionalism in education } \\
\text { - Continue to improve our organizational effectiveness and capability[10]. }\end{array}$ \\
\hline $\begin{array}{l}\text { USA } \\
\end{array}$ & $\begin{array}{l}\text { CAEP goals: } \\
\text { - To raise the bar for educator preparation } \\
\text { - To promote continuous improvement } \\
\text { - To advance research and innovation } \\
\text { - To increase accreditation's value } \\
\text { - To be a model accrediting body } \\
\end{array}$ \\
\hline Aust & $\begin{array}{l}\text { AITSL has two key objectives: } \\
\text { - Improvement of teachers' quality through continuous development of teacher education } \\
\text { - Accountability of contributors for the delivering of excellent teacher education programs that are } \\
\text { transparent and of rigorous standards and accreditation processes[8] }\end{array}$ \\
\hline Pakistan & $\begin{array}{l}\text { NACTE's mission is to: } \\
\text { Ensure high quality teacher education programs as an integral part of higher education through a } \\
\text { sustained professional internal academic audit and external accreditation } \\
\text { Specific goals or objectives have not been outlined by NACTE[9]. }\end{array}$ \\
\hline
\end{tabular}


Table 3 exemplifies the sheer dedication and commitment all four accreditation bodies have for facilitating and ensuring highest standards of teaching and learning mechanisms in their respective countries.

\section{Table-4: Eligibility and Qualification Standards}

\begin{tabular}{|c|c|}
\hline Scotland & $\begin{array}{l}\text { TE programs must: } \\
\text { - have effective partnership arrangements } \\
\text { have an appropriate balance of professional studies, subject studies and relevant school } \\
\text { educational placement experience } \\
\text { - contain clear arrangements for updating in line with national developments and new } \\
\text { perspectives arising from educational research } \\
\text { - } \text { meet the QAA (Quality Assurance Agency) Benchmarks which are within the Standard for } \\
\text { - Initial Teacher Education } \\
\text { allow student teachers to meet the Standard for Initial Teacher Education[10] }\end{array}$ \\
\hline USA & $\begin{array}{l}\text { To be eligible for CAEP accreditation, the TE institution must be accredited by an accrediting body } \\
\text { which is recognised by the U.S. Department of Education and the Council on Higher Education } \\
\text { Accreditation [12]. }\end{array}$ \\
\hline Australia & re-condition for any TE institution to work [3]. \\
\hline Pakistan & $\begin{array}{l}\text { TE programs offered at: } \\
\text { - institutions chartered by the Federal or the provincial government } \\
\text { - institutions affiliated with the chartered or degree-awarding institutions } \\
\text { institutions offering degree programs under affiliation/collaboration with foreign universities } \\
\text { under the approval of HEC[13] }\end{array}$ \\
\hline
\end{tabular}

Eligibility and Qualification Standards outlined in Table 4 for Scotland, USA, Pakistan, and Australia are in harmony and synchronization with each other. All four require TE programs to be offered by the nationally and provincially accredited institutions. Australia clearly stands out among the four as $100 \%$ of its TE programs have an acceptable accreditation status.

Table-5: Acknowledgement and Acceptance

\begin{tabular}{|l|l|}
\hline Scotland & $\begin{array}{l}\text { 'All courses must be acceptable to the General Teaching Council for Scotland (GTCS) as leading to } \\
\text { registration as a primary or secondary teacher.' This was the part of Guidelines for Initial Teacher } \\
\text { Education Courses in Scotland [14] stated by Scottish Executive Education Department [15] }\end{array}$ \\
\hline USA & $\begin{array}{l}\text { Accreditation provides feedback for the development and update of professional teaching standards in } \\
\text { the majority of US states [11]. }\end{array}$ \\
\hline Australia & $\begin{array}{l}\text { Accreditation helps in improving professional position and determination to better quality within the } \\
\text { pre-service teacher-education sector [3]. }\end{array}$ \\
\hline Pakistan & $\begin{array}{l}\text { Teacher Education Institutions primarily pursue the accreditation process due to its MANDATORY } \\
\text { nature. }\end{array}$ \\
\hline
\end{tabular}

Table 5 suggests that the accreditation status carries significant weight in Scotland, USA, and Australia. Here, the accreditation status functions as a stepping-stone for high quality teaching and school leadership. Therefore, the graduates of accredited TE program are given preference in teaching jobs. In Pakistan, accreditation status only reflects the quality of the offered program(s) through the ranking given. Prospective teachers who graduate from the accredited TE program do not enjoy any real-time advantage over the prospective teachers who graduate from the non-accredited TE program.

Table-6: Criterion for Assessment

\begin{tabular}{|c|l|}
\hline Scotland & $\begin{array}{l}\text { The Standard describes the knowledge, skills, and dispositions expected of graduates of accredited TE } \\
\text { programs in the form of 'Benchmarks': } \\
\text { Benchmark 1: Professional values and personal commitment } \\
\text { Benchmark 2: Professional skills and abilities } \\
\text { Benchmark 3: Professional knowledge and understanding[6] }\end{array}$ \\
\hline USA & CAEP has five standards as follows: \\
& Standard 1: Content and Pedagogical Knowledge \\
& Standard 2: Clinical Partnerships and Practice \\
& Standard 3: Candidate Quality, Recruitment, and Selectivity \\
& Standard 4: Program Impact \\
& Standard 5: Provide Quality Assurance and Continuous Improvement [7] \\
\hline
\end{tabular}




\begin{tabular}{|l|l|}
\hline Australia & AITSL sets out the Program Standards that an initial teacher education program MUST meet for \\
& accreditation: \\
& Standard 1: Outcomes of the Program \\
& Standard 2: Development of the Program \\
& Standard 3: Entrants of the Program \\
& Standard 4: Content and Structure of the Program \\
& Standard 5: School Partnerships \\
& Standard 6: Resourcing and Delivery of the Program \\
& Standard 7: Information and Evaluation of the Program[8] \\
\hline Pakistan & NACTE has recognized the following seven standards to serve as the foundation for assessment of TE \\
& programs: \\
& Standard 1: Curriculum and Instruction \\
& Standard 2: Assessment and Evaluation System \\
& Standard 3: Physical Infrastructure, Academic and Learning Resources \\
& Standard 4: Human Resources \\
& Standard 5: Finance and Management \\
& Standard 6: Research and Scholarship \\
& Standard 7: Community Links and Outreach[16]
\end{tabular}

The criterion for Assessment in Table 6 outlines the rigorous and detailed benchmarks and standards as quality assurance measures. All four TE accreditation models are at par with this parameter.

Table-7: Operational Cost

\begin{tabular}{|c|l|}
\hline Scotland & GTCS is fully funded by registered teachers. \\
\hline USA & CAEP is mainly financed through fee paid by recognized organisations. \\
\hline Australia & AITSL is financed by the government of Australia. \\
\hline Pakistan & $\begin{array}{l}\text { NACTE is primarily funded through the fees paid by the TE institutions pursuing accreditation. It is believed } \\
\text { that since NACTE is a federal body, it may also receive some additional financial support from HEC. }\end{array}$ \\
\hline
\end{tabular}

According to Table 7, the accreditation bodies of Pakistan, Scotland, and the USA are financially independent and have sustainable financial models. Australia, on the other hand, is publically funded.

Table-8: Accreditation Process

\begin{tabular}{|c|c|}
\hline Scotland & $\begin{array}{l}\text { In the case of a program being accredited for the first time, there are normally four } \\
\text { stages: } \\
\text { - Expression of Interest } \\
\text { - University Approval/Validation } \\
\text { - Accreditation } \\
\text { - Approval of Scottish Ministers[10] }\end{array}$ \\
\hline USA & $\begin{array}{l}\text { The accreditation process includes the following steps: } \\
\text { - The initial self- evaluation } \\
\text { - On-site visit by the team of peer evaluators } \\
\text { - Ongoing review } \\
\text { - The final decision[17] }\end{array}$ \\
\hline Australia & $\begin{array}{l}\text { The main steps of the accreditation process are: } \\
\text { - Institution submits an application for accreditation of the program or } \\
\text { - } \text { reaccreditation } \\
\text { AITSL Panel assesses program application and puts up a draft report for } \\
\text { - Iccreditation } \\
\text { - } \text { Institution goes through the draft report and gives the feedback } \\
\text { - } \text { AITSL publishes decision and status of the program accredited[8] }\end{array}$ \\
\hline Pakistan & $\begin{array}{l}\text { The key steps include: } \\
\text { - Preparation of Accreditation documents, including self-evaluation report } \\
\text { - Visit by External Evaluators } \\
\text { - The Final Decision } \\
\text { - The Decision Review, if required[18] }\end{array}$ \\
\hline
\end{tabular}


All four accreditation processes given in Table 8 resonate well with each other. All have a 4-step review process that begins with the self-evaluation or internal review and completes with the awarding of 'accreditation statuses.

Table-9: Duration

\begin{tabular}{|l|l|}
\hline Scotland & Accreditation status valid for Six Years \\
\hline USA & Accreditation status valid for Five Years \\
\hline Australia & Accreditation status valid for Five Years \\
\hline Pakistan & Accreditation status valid for Three Years \\
\hline
\end{tabular}

Table 9 reflects that Pakistan must take measures to increase the validation period for accreditation. The review of this parameter proposes that Pakistan should also make accreditation status valid for at least five years, making it more in line with International practices.

Table-10: Complimentary Quality Assessment

\begin{tabular}{|c|c|}
\hline Scotland & $\begin{array}{l}\text { When a person successfully completes a teacher education program at a Scottish university, he/she must } \\
\text { receive a teaching qualification (TQ). By law, a teacher must register with the GTCS before he/she can be } \\
\text { employed as a teacher in a Scottish education authority nursery, primary, secondary or special school [15]. }\end{array}$ \\
\hline USA & $\begin{array}{l}\text { Each state in the USA demands from every teacher-candidate to get a teaching license first before entering } \\
\text { the profession. For that, the teacher must: } \\
\text { - Have at least a bachelor's degree } \\
\text { - } \text { Complete an approved, accredited education program } \\
\text { - Pass a state licensure test[19] }\end{array}$ \\
\hline Australia & $\begin{array}{l}\text { Licensing of Teachers in Australia: } \\
\text { - } \text { Entrance Examination/Test } \\
\text { - } \text { Probationary Period } \\
\text { - Granted full registration after one year of teaching service to meet the professional standards of the } \\
\text { - Board. } \\
\text { Evaluation and Rewards[20] }\end{array}$ \\
\hline Pakistan & $\begin{array}{l}\text { NACTE does not enjoy any complimentary support in assuring high teacher quality from any other national } \\
\text { level body. To this date, there exists no teacher registration or certification agency either at provincial or } \\
\text { national level. }\end{array}$ \\
\hline
\end{tabular}

Table 10 outlines the benefits that the prospective teachers from the accredited TE programs enjoy in Scotland, USA, and Australia. Here, the accreditation status functions as a stepping-stone for teacher registration and certification. Pakistan, on the other hand, does not have any teacher registration or certification agency either at provincial or national level.

\section{DisCUSSION AND RECOMMENDATIONS}

The procedure to award the 'accreditation' status to TE providers is parallel to a great extent amongst the countries discussed here. All four accreditation bodies (GTCS, CAEP, AITSL, and NACTE) determine the eligibility and appropriateness of the institution or the program which generally begins with a self-study from the institution or the program. This internal evaluation is followed by the site visit of review team who examines the teacher education program(s) against the self-study report as well as predefined parameters and standards, and finally, the accreditation decision is issued.

Despite reasonably similar accreditation methodology, there exist considerable differences in operation and ideology among the four accreditation models discussed in this paper. This diversity in approach allows a constructive policy and practice borrowing between the countries to facilitate the effective improvement of teacher education quality.

GTCS, the Scottish teacher education accreditation body, operates under non-federal jurisdiction where the accreditation processes are closely linked to teacher registration and the school system generally. This allows an extraordinary advantage of keeping teacher education courses well-aligned with the needs and requirements of school teachers. This close-knit arrangement prepares pre-service teachers more realistically and efficiently for their future roles as teachers. 
As a federal accreditation body, NACTE has more in common with CAEP than with AITSL. Pakistan and USA have more teacher education institutions in comparison to Australia. Australia has about 35 institutions offering the teacher education courses while the USA has approximately 1500 TE programs [21]. In Pakistan, NACTE has engaged with about 237 institutions country-wide and accredited almost 151 teacher education programs [22].

Another feature that both NACTE and CAEP have in common is the alignment of teacher education accreditation models with well developed, agreed upon professional teaching standards in their respective contexts. NACTE developed a set of seven standards and a conceptual framework named as the National Standards for Accreditation of Teacher Education Programs (NSATEP). These standards were created in alignment with National Professional Standards for Teachers in Pakistan (NPSTP). Australia has also been advancing in aligning the AITSL standards for teacher education with the current National Framework for Teaching Standards [3].

GTCS, CAEP, and AITSL are well supported by rigorous teacher certification and registration mechanisms, enhancing the impact of accreditation status. Accreditation status of TE program, in many cases, functions as an endorsement for the teacher candidate to get the teaching license or certificate. This facilitates a two-way filtration, accountability, and monitoring in teacher preparation process, first when teacher candidates are pursuing the teacher education programs and second when they are seeking a teaching position upon graduation. Pakistan can learn a great deal from these models and should work on establishing an independent body for teacher certification. This would mark a significant improvement in teaching and learning in Pakistan.

Pakistan may also learn in terms of how GTCS and CAEP operate as voluntary accreditation bodies and do not force TE providers to engage in accreditation process against their wills. Both invite the voluntary participation of TE programs and therefore focus on fewer teacher education programs targeting the higher level of quality through in-depth involvement and thorough follow-ups. NACTE, on the other hand, has the policy of mandatory accreditation for all teacher education programs across the country. While this mandatory participation may pull teacher education programs into the mainstream, it can also be problematic. NACTE must ensure that they develop the capacity (infrastructure, human resource, and funds) to meet the increasing workload without compromising on the quality of accreditation process.

Through this review, it has become more evident that NACTE's qualifications and standards to accredit teacher education programs in Pakistan are largely on par with the international teacher education models. However, in terms of implementation, NACTE must improve the following key areas: make accreditation purpose and practices more transparent to all TE providers; advocate accreditation mechanism as an inclusive process rather than exclusive; extend the accreditation duration to at least five years; establish regional teacher-accreditation teams to thoroughly engage with TE providers both pre and post accreditation; communicate accreditation results with real-time recommendations for the improvement; follow-through on recommended actions on annual basis; argue for the credible teacher registration and certification bodies at provincial and national level; and encourage the synchronization of accreditation standards with the provincial frameworks of in-service teacher education.

It is the time that policymakers and educationists in Pakistan recognize the inherent value of quality education for its society and citizens. All stakeholders of teacher education must facilitate NACTE in ensuring the supply of competent and productive teachers. NACTE must benefit from the exemplary policies and practices of teacher education accreditation across the globe to strengthen the education system in Pakistan.

\section{REFERENCES}

1. Sywelem, M. M. G. (2009). Accreditation Models in Teacher Education: The cases of the United States, Australia, and India. International Journal of Education and Research, 2(3), 1-12.

2. Darling-Hammond, L. (2006). Securing the Right to Learn: Policy and Practice for Powerful Teaching and Learning. Educational Researcher, 35(7), 13-24.

3. Ingvarson, L., Elliott, A., Kleinhenz, E., and McKenzie, P. (2006). Teacher Education Accreditation: A review of national and international trends and practices, Teacher Education, 1.

4. Satyanarayana, N., \& Srivastava, R. (2009). Accreditation: Panacea for Producing Better Professionals.

5. CHEA. (2010). The Value of Accreditation. Washington, DC: Council for the Accreditation of Educator Preparation.

6. GTCS. (2006a). Policy Statement: Accreditation of Programmes of Initial Teacher Education in Scotland. Edinburg: General Teaching Council for Scotland.

7. CAEP. (2013a). CAEP Accreditation Standards. Washington, DC: Council for the Accreditation of Educator Preparation.

8. Timperly, H. (2011). A background paper to inform the development of a national professional development framework for teachers and school leaders. Australian Institute for Teaching and School Leadership (AITSL), 1-26.

9. NACTE. (2009a). NACTE: An Introduction. Islamabad: National Accreditation Council for Teacher Education. 
10. GTCS. (2006b). Memorandum on Entry Requirements to Programmes of Initial Teacher Education in Scotland. Edinburg: General Teaching Council for Scotland.

11. CAEP. (2013b). Annual Report to the public, the states, policymakers, and the education profession. Washington, DC: Council for the Accreditation of Educator Preparation.

12. CAEP. (2013c). Policy Manual. Washington, DC: Council for the Accreditation of Educator Preparation.

13. NACTE. (2009c). Manual of Accreditation for Teacher Education Institutions. Islamabad: National Accreditation Council for Teacher Education.

14. Jiang, C., Ting, A. T., \& Seed, B. (1998). PPAR- $\gamma$ agonists inhibit production of monocyte inflammatory cytokines. Nature, 391(6662), 82-86.

15. GTCS. (2013). Guidelines for Initial Teacher Education Programmes in Scotland. Edinburg: General Teaching Council for Scotland.

16. NACTE (2009b). National Standards for Accreditation of Teacher Education Programs. Islamabad: National Accreditation Council for Teacher Education.

17. Alstete, J. W. (2004). Accreditation Matters: Achieving Academic Recognition and Renewal. ASHE-ERIC Higher Education Report. Volume 30, Issue 4. Jossey-Bass, an Imprint of Wiley. 10475 Crosspoint Blvd, Indianapolis, IN 46256.

18. NACTE. (2009d). Accreditation Processes and Procedures. Islamabad: National Accreditation Council for Teacher Education.

19. Roth, D., \& Swail, W. S. (2000). Certification and Teacher Preparation in the United States. Washington, DC: Educational Policy Institute.

20. RA- International Reading Association. (2008). State of Teacher Education in the Asia-Pacific Region, UNESCO.

21. Wang, A. H., Coley, A. B., \& Phelps, R. P. (2003). Preparing Teachers around the World. Policy Information Report.

22. NACTE. (2015). NACTE Annual Report 2014-2015. Islamabad: National Accreditation Council for Teacher Education.

23. Australian Institute for Teaching and School Leadership. (2013a). Annual Report Carlton South, VIC: Education Services Australia.

24. Australian Institute for Teaching and School Leadership. (2011). Accreditation of initial teacher education programs in Australia: Standards and procedures. Carlton South, VIC: Education Services Australia.

25. Australian Institute for Teaching and School Leadership. (2013b). Accreditation of initial teacher education programs in Australia: Guide to the accreditation process. Carlton South, VIC: Education Services Australia. 